\title{
Process simulation of bioethanol production from brown algae
}

\author{
Peyman Fasahati*, J. Jay Liu* \\ *Department of Chemical Engineering, Pukyong National University, Busan, Korea \\ (e-mail:fasahati@pknu.ac.kr; jayliu@pknu.ac.kr
}

\begin{abstract}
Steady state ethanol production from brown algae (Saccharina japonica) based on 100,000 ton/year dry feed was simulated using Aspen Plus V7.3 software. Different process units including saccharification, fermentation and purification were modeled based on experimental works obtained from literature. Acid thermal hydrolysis using $\mathrm{H}_{2} \mathrm{SO}_{4}$ and simultaneous saccharification and fermentation (SSF) were used and modeled in this simulation. Distillation columns along with molecular sieves were used to recover ethanol from the raw fermentation broth to produce $99.5 \%$ ethanol. This simulation is the first attempt in literature to evaluate large-scale production of ethanol from macroalgae and allows its economic analysis.
\end{abstract}

Keywords: Bioethanol, Process simulation, Seaweed, Brown algae, Saccharification, Fermentation

\section{INTRODUCTION}

Biofuels are gaining increased public and scientific attention, driven by factors such as oil price spikes, the need for increased energy security, and concern over greenhouse gas emissions from fossil fuels. It can be obtained from renewable sources containing starch, sugar, or cellulose, such as potatoes, corn, corn cobs and stalks, grains, and wood. One of main problems with using crops or woods as feedstock is that they will affect directly crop prices and will result in destruction of forests. Therefore, seaweed or macroalgae as a solution for this problem has been introduced recently. Some of advantages in using seaweed as feedstock include simple cultivation and possible productiveness. It also has easier manufacturing process (No lignin removal) with a higher $\mathrm{CO}_{2}$ fixation ability.

These advantages motivated researchers to report substantial amounts of experimental works showing possibility of production of ethanol from seaweed. But there is no large scale simulations developed yet to examine possibility of industrialization of the process. On the other hand, it is impossible to explore all the important features and variables of such a process via experimental investigations alone. Computer simulation is an invaluable tool for the analysis, design, and economic evaluation of the individual process units, and for comparing and optimizing various process alternatives. Computer simulations naturally cannot replace experimental studies, but are more of a tool used in the planning and evaluation of the experiments.

Brown algae as a seaweed is evolutionarily diverse and abundant in the world's oceans and coastal waters. The seaweed industry has an estimated total annual value of 5.5 to 6 billion US\$, with 7.5 to 8 million tons of naturally grown and cultivated seaweed harvested worldwide. Seaweed is mainly used in food products for human consumption, which generates approximately 5 billion US\$ per year, with the remainder used for production of extracted hydrocolloids, fertilizers, and animal feed additives (Adams et al., 2009;
McHugh et al., 2003). Brown seaweed has a high content of easily degradable carbohydrates, making it a potential substrate for the production of liquid fuels. The carbohydrates of brown seaweed are mainly composed of alginate, laminaran, mannitol, fucoidan and cellulose in small amounts (Horn et al., 2000).

Alginate is the major structural component of the brown algal cell wall, and mainly consists of $\beta$-D-Mannuronic acid and $\alpha$ L-Guluronic acid units. In a wide range of industrial applications, alginates are essential compounds as thickening, gelling or stabilizing agents (McHugh, 1987). Laminaran is a linear polysaccharide of $\beta-(1,3)$-D-glucose in which the chain terminates with D-mannitol with low levels of branching at $\beta$ - $(1,6)$ - glycosidic linkages (Horn et al., 2000; Myklestad S., 1987).

Mannitol, a sugar alcohol derived from mannose, is also one of the main sugar components of brown seaweed. Mannitol, produced by photosynthesis, is universally found in brown algae and can account for $20-30 \%$ dw(dry weight) in some Laminaria species (Horn et al, 2000). Mannitol exhibits hydrating and antioxidant properties used in numerous cosmetic and pharmaceutical applications (Iwamoto et al, 2005). Mannitol is not readily fermented. It is oxidised to fructose by mannitol dehydrogenase, a reaction that generates $\mathrm{NADH}$. Regeneration of NAD+ requires oxygen (active electron transport chain) or transhydrogenase, which converts NADH to NADPH. Thus, many microorganisms are not able to carry out strictly anaerobic fermentation of mannitol (Van Dijken et al., 1986)

Fucoidan, the sulphated polysaccharide containing substantial percentages of 1-fucose and sulphate ester groups, are constituents of brown algae (Patankar et al., 1993). In spite of the many studies attempting to determine the fine structure of the fucoidan, only few examples of regularity were found. Linkages, branching, sulphate positions and composition of monosaccharaides are strongly differing, and thus, the relationship between structure and biological activity is not 
established so far (Ponce et al., 2003). The elucidation of the structure is not concluded yet, and thus, the algae cannot be grouped by their fucoidan structure.

\section{PROCESS SIMULATION}

For simulation, Aspen Plus ${ }^{\circledR} \quad$ v7.3 software (Aspen Technology Inc. Cambridge, Massachusetts, USA) was used for this work. The procedures for process simulation mainly involve: defining chemical components, selecting the thermodynamic model, choosing proper operating units and setting up input conditions (flow rate, temperature, pressure, etc.). As shown in figure 1 , the ethanol production process that we simulated consists of three major units, feed pretreatment, simultaneous saccharification and fermentation (SSF), and finally purification. The non-random two-liquid model (NRTL) property calculation method was selected. In next sections feed composition, assumed conversions for this simulation and three units of simulation will be explained. It is important to note at the outset that algal biofuel technology is still at the lab-scale or at the very early pilot stage of development. This study attempts to simulate an ethanol production plant from brown algae based on current state of art technology available for ethanol production. As such it is possible that some operating conditions and conversions may need to be revised based on future developments in algal biofuel production.

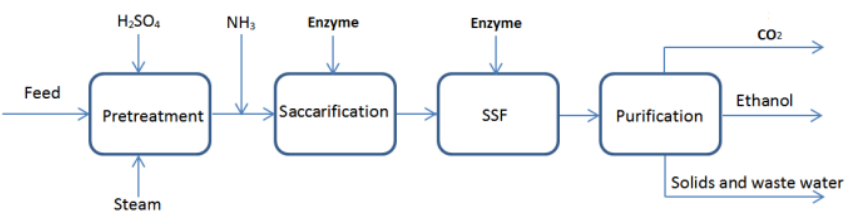

Fig. 1. A simplified process flow diagram for ethanol production.

\subsection{Feed composition}

Generally, the chemical composition of brown algae varies considerably between species, throughout the year and between habitats. Brown algae exposed to seasonal changes usually accumulate mannitol and laminaran in the light season (spring to autumn), and consume these storage carbohydrates in the dark season (Haug et al., 1954). The composition and proximate analysis of several seaweeds is listed in Table 1(Jang et al., 2011).

The composition that assumed in this simulation is given in table 2. The first column is the averaged composition and second column is the composition that we used in our simulation. This data is based on literature data and averaged between several brown algae (John et al., 1998; Horn S. G., 2000a; Rioux et al., 2007; Jang et al., 2011). With a main focus on Saccharina japonica which is widely cultivated in Korea, China and Japan.

Fucoidan also can have different structures in different algae (Rioux et al., 2007). Zhang et al. find the chemical composition of fucoidan in Laminaria japonica as follows: total sugar content $48 \%$, fucose content $28 \%$, and sulphate content $29 \%$. Neutral monosaccharide analysis by Gas-liquid chromatography showed that fucose and galactose are present in fucoidan with their molar ratio being 1.0:0.24. Molecular weight was determined to be 189,000 (Zhang et al., 2005).

Since exact structure of fucoidan was not known, we decided to distribute its composition equally between ash and laminaran, because parts of fucoidan sugar are galactose and fucose which produce the same amount of ethanol as Glucose. Also half of the fucoidan will remain unreacted and solid which we considered as ash. This would be a good assumption for this simulation.

\section{Table 1. Compositions of various seaweeds}

\begin{tabular}{|c|c|c|c|c|}
\hline \multirow{2}{*}{ Seaweed } & \multicolumn{4}{|c|}{ Composition (\%, w/w) } \\
\cline { 2 - 5 } & $\begin{array}{c}\text { Crude } \\
\text { protein }\end{array}$ & $\begin{array}{c}\text { Crude } \\
\text { lipid }\end{array}$ & $\begin{array}{c}\text { Crude } \\
\text { ash }\end{array}$ & $\begin{array}{c}\text { Total } \\
\text { carbohydrate } \\
\text { (fiber) }\end{array}$ \\
\hline $\begin{array}{c}\text { Saccharina } \\
\text { japonica }\end{array}$ & 10.6 & 1.6 & 21.8 & $66.0(6.3)$ \\
\hline $\begin{array}{c}\text { Sargassum } \\
\text { fulvellum }\end{array}$ & 19.9 & 0.5 & 35.1 & $44.5(3.5)$ \\
\hline $\begin{array}{c}\text { Undaria } \\
\text { pinnatifida }\end{array}$ & 18.3 & 1.8 & 28.0 & $52.0(3.6)$ \\
\hline $\begin{array}{c}\text { Hizikia } \\
\text { fusiforme }\end{array}$ & 13.9 & 0.4 & 26.6 & $59.0(4.2)$ \\
\hline $\begin{array}{c}\text { Enteromor } \\
\text { pha linza }\end{array}$ & 31.6 & 1.8 & 29.2 & $37.4(2.4)$ \\
\hline $\begin{array}{c}\text { Gelidium } \\
\text { amansii }\end{array}$ & 18.3 & 0.0 & 7.4 & $74.4(11.6)$ \\
\hline
\end{tabular}

However, the total amount of fucoidan is very small compared to other structural carbohydrates of brown algae and it will not affect the economy of process greatly.

Table 2. Brown algae composition

\begin{tabular}{|c|c|c|}
\hline \multirow{2}{*}{ Component } & Base of design & Used in simulation \\
\cline { 2 - 3 } & Dry wt \% & Dry wt \% \\
\hline Ash & 23.63 & 25.48 \\
\hline Algin & 27.78 & 27.78 \\
\hline Laminaran & 16.67 & 18.52 \\
\hline Mannitol & 14.81 & 14.81 \\
\hline Fucoidan & 3.7 & - \\
\hline Cellulose & 6 & 6 \\
\hline Protein & 7.41 & 7.41 \\
\hline
\end{tabular}

\subsection{Conversion rates}

There are numerous studies and experimental works in the field of saccharification and fermentation of brown algae along with problems to use them as a reference for simulation. Each study uses a specific type of brown algae that belongs to different geographical locations. Therefore, amount of the conversions reported for one type of algae cannot necessarily be applied to other types. For example alginate degredation may be seriously affected by polyphenols and divalent metal ions present in the tissue during anaerobic digestion of brown seaweeds which is in different amounts between different algae (Moen et al., 
1997). Also, using different types of enzymes, bacteria, or microorganisms can compound complexity of the problem.

Another problem is to find out conversion rates for every component entering the reaction. There is no experimental work that reports a conversion rate of each component in the mixture unless one specific component is used for experiment. For example Horn et al. (2000c) have done some experiments on conversion of mannitol to ethanol. They showed that under oxygen-limiting conditions, the bacteria can grew and produce ethanol in a synthetic mannitol medium with a yield of $0.38 \mathrm{~g}$ ethanol ( $\mathrm{g}$ mannitol $)^{-1}$. Table 3 gives a summary of conversion rates for saccharification and fermentation of brown algae. In this study to find conversion rates for every single component, some back calculations performed using litreture data.

\section{Table 3. Saccharification and fermentation conversion rates from literature data.}

\begin{tabular}{|c|c|c|c|}
\hline Ref. & Material & $\begin{array}{c}\text { Saccharification } \\
\text { Yield }\end{array}$ & $\begin{array}{l}\text { Fermentation } \\
\text { Yield (Ethanol) }\end{array}$ \\
\hline $\begin{array}{l}\text { Jang et } \\
\text { al., } 2011\end{array}$ & $\begin{array}{l}\text { Laminaria } \\
\text { japonica }\end{array}$ & $69.1 \%$ & $\begin{array}{c}33.3 \% \\
\text { theoretical yield }\end{array}$ \\
\hline $\begin{array}{c}\text { Ge et al., } \\
2011\end{array}$ & $\begin{array}{l}\text { Laminaran } \\
\text { \& Mannitol }\end{array}$ & $277.5 \mathrm{mg} / \mathrm{g}$ & $\begin{array}{c}41.2 \% \\
\text { theoretical yield }\end{array}$ \\
\hline $\begin{array}{l}\text { Moen et } \\
\text { al., 1997a }\end{array}$ & Alginate & $\begin{array}{l}50-87 \% \text { of } \\
\text { alginate }\end{array}$ & \\
\hline $\begin{array}{l}\text { Horn et } \\
\text { al., 2000b }\end{array}$ & $\begin{array}{l}\text { Laminaria } \\
\text { hyperborea } \\
\text { extracts }\end{array}$ & & $\begin{array}{c}0.43 \\
g / g \text { substrate }\end{array}$ \\
\hline $\begin{array}{l}\text { Horn et } \\
\text { al., 2000c }\end{array}$ & $\begin{array}{l}\text { synthetic } \\
\text { mannitol } \\
\text { medium }\end{array}$ & & $\begin{array}{c}0.38 \\
\text { g ethanol } / \mathrm{g} \\
\text { mannitol }\end{array}$ \\
\hline $\begin{array}{l}\text { Wargacki } \\
\text { et al. } \\
2012\end{array}$ & $\begin{array}{l}\text { Laminaria } \\
\text { japonica }\end{array}$ & & $\begin{array}{c}0.281 \mathrm{~kg} \\
\text { ethanol } / \mathrm{kg} \text { dry } \\
\text { seaweed }\end{array}$ \\
\hline $\begin{array}{l}\text { Horn et } \\
\text { al., 2000c }\end{array}$ & $\begin{array}{l}\text { Glucose } \\
\text { and } \\
\text { mannitol }\end{array}$ & - & $\begin{array}{c}0.4 \\
\mathrm{~g} / \mathrm{g}(\text { glucose } \\
\text { mannitol })\end{array}$ \\
\hline $\begin{array}{c}\text { Humbird } \\
\text { et al., } \\
2011\end{array}$ & Cellulose & $91 \%$ & $95 \%$ \\
\hline
\end{tabular}

Conversion rates considered in this simulation are shown in table 4. These numbers is a percentage of the theoretical yield. For example, the statement " $95 \%$ conversion of glucose to ethanol" means that $95 \%$ of the glucose in the system was consumed in the following reaction:

$$
\text { Glucose } \rightarrow 2 \text { Ethanol }+2 \mathrm{CO}_{2}
$$

Which has a theoretical yield of $0.51 \mathrm{~g}$ ethanol $/ \mathrm{g}$ glucose. These data obtained from back calculations and averaging based on data from literature mentioned before.
Table 4. Conversion rates used in simulation

\begin{tabular}{|c|c|c|c|c|}
\hline & \multicolumn{3}{|c|}{ Saccharification } & \multirow{2}{*}{$\begin{array}{c}\text { Ethanol } \\
\text { conversion }\end{array}$} \\
\hline & $\begin{array}{c}\text { Acid } \\
\text { thermal } \\
\text { Hydrolysis }\end{array}$ & $\begin{array}{c}\text { Enzymatic } \\
\text { Saccharific } \\
\text { ation }\end{array}$ & Tot. & \\
\hline Alginate & $8 \%$ & $50 \%$ & $54 \%$ & $60 \%$ \\
\hline Laminaran & $10 \%$ & $85 \%$ & $86 \%$ & $95 \%$ \\
\hline Cellulose & $10 \%$ & $95 \%$ & $95 \%$ & $95 \%$ \\
\hline Mannitol & \multicolumn{3}{|c|}{$95 \%$ of mannitol dissolve in water } & $85 \%$ \\
\hline
\end{tabular}

\subsection{Pretreatment}

The pretreatment process converts most of the carbohydrates in the feedstock to soluble sugars (D-mannuronate, Lguluronate, D-glucose and L-glucuronate) by hydrolysis reactions. Figure 2 shows a process flow diagram of this section. Pretreatment is carried out in two stages. The first stage is to heat up the feed stream by adding steam and to add $\mathrm{H}_{2} \mathrm{SO}_{4}$ for thermal acid hydrolysis. Second stage is to use enzymes for saccharification and then SSF. The best condition reported for acid hydrolysis is $10 \%(\mathrm{w} / \mathrm{v})$ seaweed slurry, $40 \mathrm{mM} \mathrm{H}_{2} \mathrm{SO}_{4}$ at $121^{\circ} \mathrm{C}$ and enzymatic SSF (Choi et al., 2007; Jang et al., 2011). At these conditions, total yield of the Saccharification is $75 \%$ of total carbohydrates.

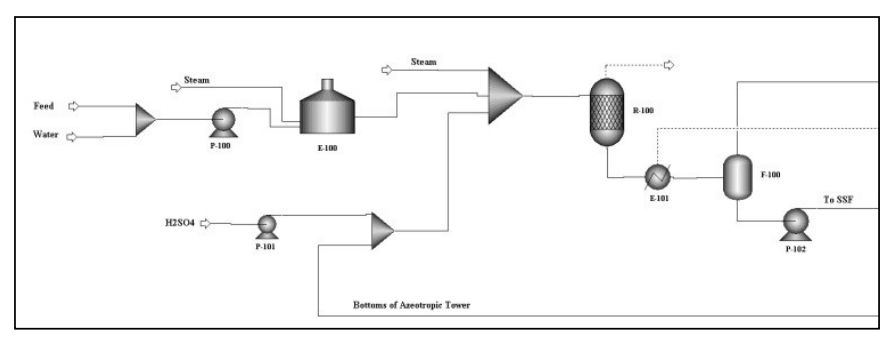

Fig. 2. A process flow diagram of pretreatment section.

Two steam flow rate adjusters were used in preheater and reactor to reach $121^{\circ} \mathrm{C}$ temperature. Water adjuster was used to maintain a $10 \%(\mathrm{w} / \mathrm{v})$ solid ratio at pretreatment reactor inlet stream. Hydrolysis reactions are catalysed using dilute sulphuric acid and heat from steam. $\mathrm{H}_{2} \mathrm{SO}_{4}$ design spec was used to maintain $\mathrm{H}_{2} \mathrm{SO}_{4}$ concentration at $40 \mathrm{mM}$ in the slurry. Conversion rates of thermal acid hydrolysis given in table 4 assigned to each Carbohydrate component. Alginate convert to its unit monomers, D-Mannuronic acid and L-Guluronic acid with an M:G ratio of 1.35. Laminaran and cellulose also degrades to glucose. Mannitol solubility is high and it is assumed that $95 \%$ of the mannitol is dissolved in water. The partially converted slurry sent off to SSF Unit.

\subsection{Fermentation}

In this section materials are further saccharified and fermented to ethanol. Figure 3 gives a schematic of this process. The slurry received from the pretreatment section is first neutralized with Ammonia. Ammonia is selected for neutralization instead of conventional Lime, because over liming causes a significant amount of sugar loss in the liquor (as much as $13 \%$ ) by side reactions occurring at high $\mathrm{pH}$. 
Although ammonia is considerably more expensive than lime, the economic benefits of reduced sugar loss and reduced capital cost make ammonia a more economical alternative over lime (Jennings et al, 2008). The high miscibility of ammonia also permits conditioning of the whole hydrolysate slurry and eliminates the solid-liquid separation steps (Humbird et al., 2011).

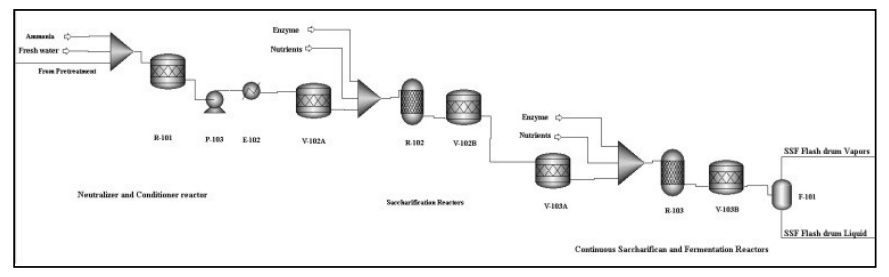

Fig. 3. A process flow diagram of SSF section.

The slurry received from the pretreatment section passes through a heat exchanger to reach the $30{ }^{\circ} \mathrm{C}$ saccharification and fermentation temperature. Before sending the slurry to SSF reactors, slurry goes to saccharification reactors for further saccharification. Conversion rates from the second column of table 4 were assigned to unsaccarified carbohydrates in slurry. The products from these reactors goes to SSF reactor for simultaneous saccharification and fermentation and sugars convert to ethanol with conversion rates given in table 4 . The products from reactor go through a flash drum. The overhead vapors contain little amounts of ethanol and are sent to adsorption column. Bottom liquids are sent to recovery section for ethanol purification.

\subsection{Purification}

The purification section separates the fermentation broth into water, anhydrous ethanol, and solids. Distillation and molecular sieve adsorption are used to recover ethanol from the raw fermentation liquid and produce $99.5 \%$ ethanol. Distillation is accomplished in two columns. The first column, called the Water remover column, removes the dissolved $\mathrm{CO} 2$ and most of the water. The second column is called the Azeotropic column, concentrates ethanol from the first column to a near azeotropic composition. See Figure 4 for a process overview of this area. The ethanol product leaves the Azeotropic column and is further dehydrated to $99.5 \%$ by vapor-phase molecular sieve adsorption. During regeneration of the molecular sieve adsorption, a low-purity ethanol stream is generated and is recycled back to the Azeotropic column for recovery.

The overhead stream from the Water remover column is fed to the ethanol adsorption column along with the vent vapours from the SSF flash drum (containing mostly $\mathrm{CO}_{2}$ but also some ethanol), to recover nearly all of the ethanol. The adsorption column effluent is fed back to the Water remover column.

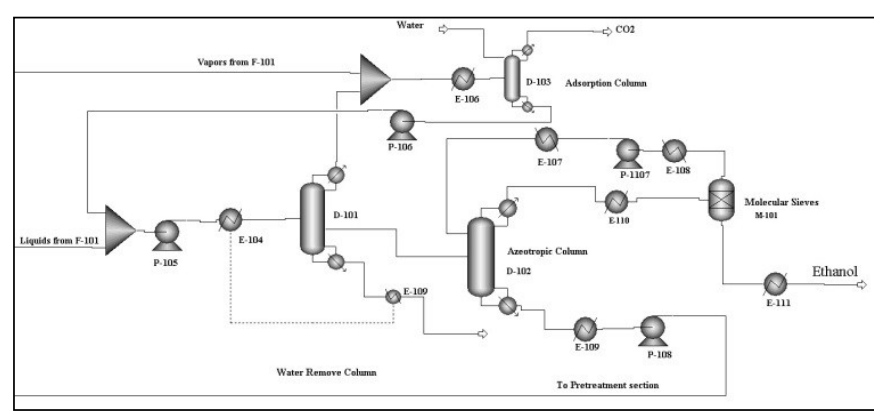

Fig. 4. A process flow diagram of purification section.

The Water remover column bottoms (stillage) stream contains the unconverted insoluble and dissolved solids, ammonium sulphate and soluble inorganic compounds from the biomass.

\section{RESULTS AND DISCUSSION}

Algae can have different composition during the year. Algae use mannitol and laminaran as food reserve during autumn and winter. So they are very rich in carbohydrates at the beginning of autumn and very poor in spring. In order to see the effects of this composition variation on ethanol production, we used two feed compositions having a 10 percent deviation in laminaran and mannitol concentrations from the compositions given in second column of table 2 . Table 5 shows new feed compositions and the effects on annual ethanol production. As we can see, $10 \%$ decrease in mannitol and laminaran weight will result in 5 weight percent less production and 5112 ton/year reduction of ethanol. In addition, $10 \%$ increase in mannitol and laminaran weight will cause in 2 percent more production and an annual 2332 ton increase in total ethanol production.

Table 5. Change in composition and effect on ethanol production

\begin{tabular}{|c|c|c|c|}
\hline (Laminaran + Mannitol) & $\mathbf{- 1 0 \%}$ & Normal & $\mathbf{+ 1 0 \%}$ \\
\hline Ash & 26.36 & 25.48 & 24.66 \\
\hline Align & 28.74 & 27.78 & 26.88 \\
\hline Laminaran & 17.24 & 18.52 & 19.71 \\
\hline Mannitol & 13.79 & 14.81 & 15.77 \\
\hline Cellulose & 6.21 & 6 & 5.81 \\
\hline Protein & 7.66 & 7.41 & 7.17 \\
\hline $\begin{array}{c}\text { Ethanol to dry feed ratio } \\
\text { (w/w) }\end{array}$ & 0.20 & 0.25 & 0.27 \\
\hline $\begin{array}{c}\text { Annual Ethanol } \\
\text { Production (ton/year) }\end{array}$ & 20248 & 25360 & 27692 \\
\hline
\end{tabular}

\section{CONCLUSIONS}

In this work, ethanol production from brown algae, based on literature data and design objectives, was simulated in aspen plus on a 100,000 ton/year dry feed basis. Different sections of the process including pretreatment, SSF and recovery are simulated in this simulation. The ethanol production resulted in a $25 \% \mathrm{w} / \mathrm{w}$ (ethanol/dry feed) and 25,360 ton/year ethanol production which is comparable with the recently reported benchmark ethanol titer derived from lignocellulosic biomass fermentation using S. cerevisiae (Lau and Dale, 2008). This 
simulation allowed examining feed composition sensitivity analysis. Effects of composition change were studied on annual ethanol production. This study allows to develops techno-economic models and use them to analyze and optimize the economics of ethanol production plant from seaweed.

\section{ACKNOWLEDGEMENT}

This work was supported by the Ministry for Food, Agriculture, Forestry and Fisheries, and by Basic Science Research Program through the National Research Foundation of Korea (NRF) funded by the Ministry of Education, Science and Technology (2010-00003056).

\section{REFERENCES}

Adams, J, J. Gallagher and I. Donnison (2009). Fermentation study on Saccharina latissima for bioethanol production considering variable pre-treatments. J Appl Phycol, 21, 569-574.

Choi, D., B.Y. Ryu, Y.L. Piao, S.k. Choi, B.W. Jo, W.S. Shin and H. Cho (2007). Studies on Saccharification from Alginate using Stenotrophomonas maltophilia, Journal of Industrial and Engineering Chemistry, 14, 182-186.

Ge, L., P. Wang and H. Mou(2011). Study on saccharification techniques of seaweed wastes for the transformation of ethanol. Renewable Energy, 36, 84-89.

Haug, A. and A. Jensen (1954). Seasonal variations in the chemical compositions of Alaria esculenta, Laminaria saccharina, Laminaria hyperborean and Laminaria digitata from northern Norway. In: Report No. 4, Norw Inst Seaweed Res, Department of Biotechnology, Trondheim, Norway.

Horn, S.J. (2000). Bioenergy from brown seaweeds, In: $\mathrm{PhD}$ Thesis, Norwegian University of Science and Technology, Department of Biotechnology.

Horn, S., I. Aasen and K. Østgaard (2000). Ethanol production from seaweed extract. $J$ Ind Microbiol, 25, 249-254.

Horn, S.J., I. Aasen and K. Østgaard (2000). Production of ethanol from mannitol by Zymobacter palmae. J Ind Microbiol Biotechnol, 24, 51-57.

Humbird, D., R. Davis, L. Tao, C. Kinchin, D. Hsu, A. Aden, P. Schoen, J. Lukas, B. Olthof, M. Worley, D. Sexton, and D. Dudgeon (2011). Process Design and Economics for Biochemical Conversion of Lignocellulosic Biomass to Ethanol. In: Technical Report, National Renewable Energy Laboratory, NREL/TP-5100-47764.

Iwamoto, K. and Y. Shiraiwa (2005). Salt-regulated mannitol metabolism in algae. Mar Biotech, 7,407-415.

Jang, J.S., Y. Cho, G.T. Jeong and S.K. Kim (2011). Optimization of saccharification and ethanol production by simultaneous saccharification and fermentation (SSF) from seaweed, Saccharina japonica. Bioprocess and biosystems engineering, DOI: 10.1007/s00449-0110611-2.

Jennings, E., A. Mohagheghi, D. Schell and N. Dowe (2008). Technical and Economic Performance of an Ammonium
Hydroxide-Based Conditioning Technology. In: $E$ Milestone Report, Document \#10379. Golden, CO: National Renewable Energy Laboratory.

Jensen, A. and A. Haug. (1956). Geographical and seasonal variation in the chemical composition of Laminaria hyperborea and Laminaria digitata from the Norwegian coast. In: Report. ser. A. no. 14. Norsk Institutt for Tang- og Tareforskning.

John S., T. Dunahay, J. Benemann and P. Roessler (1998). $A$ look back at the U.S. department of energy's aquatic species program- biodiesel from algae. In: National Renewable Energy Laboratory, Golden, Colorado 80401-3393.

Lau M.W. and B.E. Dale (2008), Cellulosic ethanol production from AFEX-treated corn stover using Saccharomyces cerevisiae 424A(LNH-ST), Proc. Natl. Acad. Sci. U.S.A. 106,1368 (2009).

Lee S.M. and J.H. Lee (2011). The isolation and characterization of simultaneous saccharification and fermentation microorganisms for Laminaria japonica utilization. Bioresource Technology, 102, 59625967.

McHugh, D.J. (2003). A guide to the seaweed industry. FAO Fisheries Technical Paper, ISBN 92-5-104958-0.

McHugh, D.J. (1987). Production, properties and uses of alginates. FAO Fish Tech Pap, 288, 58-115.

Moen, E., S. Horn and K. Østgaard (1997). Alginate degradation during anaerobic digestion of Laminaria hyperborean stipes. Journal of Applied Phycology. 9, 157-166.

Moen, E., S. Horn and K. Østgaard (1997). Biological degradation of Ascophyllum nodosum. Journal of Applied Phycology, 9, 347-357.

Myklestad, S. (1978). Beta-1,3-glucans in diatoms and brown seaweeds. In: Handbook of phycological methods, Cambridge University Press, Cambridge, UK.

Patankar, M.S., S. Oehninger, T. Barnett, R.L. Williams and G.F. Clark (1993). A revised structure for fucoidan may explain some of its biological activities. Journal of Biological Chemistry. 268, 21770-21776.

Ponce, N.M.A., C.A. Pujol, E.B. Damonte, M.L. Flores and C.A. Stortz (2003). Fucoidans from the brown seaweed Adenocystis utricularis: extraction methods, antiviral activity and structural studies. Carbohydr Res, 338, $153-165$.

Rioux, L.E., S.L. Turgeon and M. Beaulieu (2007). Characterization of polysaccharides extracted from brown seaweeds. Carbohydrate Polymers, 69, 530 537.

Ryu, M. and E.Y. Lee (2011). Saccharification of alginate by using exolytic oligoalginate lyase from marine bacterium Sphingomonas sp. MJ-3. Journal of Industrial and Engineering Chemistry, 17, 853-858.

Van Dijken J.P. and W.A. Scheffers (1986). Redox balances in metabolism of sugar by yeasts. FEMS Microbiol, Rev 32, 199-224. 
Wargacki, A.J., E. Leonard, M. N. Win, D. D. Regitsky, C. N. S. Santos, P. B. Kim, S. R. Cooper, R. M. Raisner, A. Herman, A. B. Sivitz, A. Lakshmanaswamy, Y. Kashiyama, D. Baker, Y. Yoshikuni (2012). An Engineered Microbial Platform for Direct Biofuel Production from Brown Macroalgae, SCIENCE, Vol 335, 308-313.

Zhang, Q., N. Li, T. Zhao, H. Qi, Z. Xu and Z. Li (2005). Fucoidan Inhibits the Development of Proteinuria in Active Heymann Nephritis. Phytotherapy Research, 19, $50-53$

Zubia, M., C. Payri and E. Deslandes (2008). Alginate, mannitol, phenolic compounds and biological activities of two range-extending brown algae, Sargassum mangarevense and Turbinaria ornata (Phaeophyta: Fucales), J Appl Phycol, 20, 1033-1043. 